\title{
Die funksie van die belydenis en die dogma in die struktuur van die Nederduitsch Hervormde Kerk en die implikasies daarvan vir die predikant*
}

\author{
AD Pont
}

\begin{abstract}
The function of the Confession and Doctrine in the structure of the NHK and the implications thereof for a minister of the Word.

The whole question of the function of the Confession and Doctrine in the structure of the NHK is mainly a question of church order. This matter is treated, in the first place, by looking at history and the calvinist roots of the Church. Because the Confessio Belgica names the true preaching of the Word as one of the marks of the Church, it is of paramount importance for the Church to maintain true preaching. The norm by which true preaching is measured, is the regula fidei, i e the Bible and in the second place the Confession and the Doctrine. In the form of subscription by the ministers of the Word they acknowledge that Confession is in accordance with the Word and therefore a true norm for measuring true preaching. Three cases of alleged heresy committed by ministers are examined to determine in which way the Church Councils applied the mentioned norms.
\end{abstract}

\section{INLEIDENDE OPMERKINGS}

Die vraag na die funksie van die belydenis èn die dogma in die struktuur van òns Kerk, is al vantevore gestel èn beantwoord. Dit was in die brosjure van ds M J Goddefroy van 1912, Neem niet Roomsch! toe hy hom oor die geval Ruysch van Dugteren uitgelaat het. Tog bly dit 'n vraag wat telkens weer opduik met' $n$ meerdere of mindere mate van dringendheid.

In 'n sekere sin is dit 'n suiwer kerkordelike vraag, want dit gaan om die vraag na die funksie van die belydenis in die kerklike orde. Dit word in die Kerkwet Artikel XI uiteengesit en die implikasies daarvan

- Referaat gelewer voor die Predikantevergadering van die Nederduitsch Hervormde Kerk op 17 September 1985. 
vir die predikant word in Bepaling 73.2 na vore gebring. Daarmee is die hele saak egter nog nie beredeneer of verklaar nie.

Sodra daar na 'n verklaring gevra word, kom die hele kerklike verlede in hierdie verband na vore. Sonder om in te veel historiese besonderhede te verval, moet die volgende in hierdie verband na vore gebring word.

\section{ENKELE HISTORIESE OPMERKINGS}

Ons kerklike orde word vir 'n baie groot deel bepaal deur die feit dat ons 'n Calvinistiese kerk is, 'n kerk waarvan die struktuur grotendeels bepaal word deur die kerkordenende arbeid van Johannes Calvyn. Nou gee Calvyn die volgende definisie van die kerk (Institusie IV.1.9):

'... dat oral waar ons sien dat die Woord van God suiwer verkondig en aangehoor word en die sakramente na die instelling van Christus bedien word, daar ' $n$ kerk van God is....'

Die verkondiging van die Woord is vir Calvyn van 'n besondere gewig. Hoewel hy stel dat die kerk alleen op Christus gebou is, sê hy in sy Efese-kommentaar $(2: 20)$ uitdruklik dat die kerk deur die verkondiging van die Woord op Christus gebou is. Dit is deur die verkondiging dat God self sy kerk in aansyn roep en laat groei; dit is deur die verkondiging dat die kerk vashou aan die waarheid en dit aan die opvolgende geslagte oordra. Calvyn, net soos Luther, gee aan die verkondiging, die viva vox evangelit ' $n$ besondere gewig en daarom stel Calvyn ook dat géén mens die Woord kan verkondig as hy nie daartoe deur die Heilige Gees begenadig is nie en dit beteken dat die innerlike krag van die Heilige Gees, saamgevoeg met die uiterlike stem van die prediker, die Woord uitdra en dat die predikant so 'n instrument (organum) van God is.

Dieselfde gedagte word baie nadruklik deur die byna algemeen-aanvaarde Tweede Switserse Geloofsbelydenis van 1566 in Artikel 1 gestel:

'Daarom, as hierdie Woord van God nou in die kerk geproklameer word (annunciatur) deur predikers wat wettig geroep is, glo ons dat die ware Woord van God verkondig is en deur die gelowiges (fidelibus) ontvang is. Ons glo dat nog enige ander Woord van God voorgegee of van die hemel verwag moet word. Op die woord wat verkondig is moet nou ag geslaan word (spectandum), nie op die 
dienaar wat preek nie want hoewel hy boos en ' $n$ sondaar is (malus et peccator) bly die Woord van God nogtans waar en goed.'

Daar moet egter onthou word dat die predikant as instrument nié 'n nuwe openbaring na vore moet bring nie. Die predikant ontvang die genadegawe van die Heilige Gees sodat hy die Heilige Skrif kan uitlê en verduidelik, die evangelie kan verkondig. In sy Judas-kommentaar (1:4) stel Calvyn:

' 'n Goeie en getroue pastor behoort op 'n verstandige wyse te oorweeg wat die huidige stand van die kerk nodig het sodat hy sy verkondiging kan aanpas aan die behoeftes.'

Dit beteken vir Calvyn dat die predikant alles in sy vermoë moet doen en self ook oortuig moet wees dat dit wat hy verkondig, met die boodskap van die Skrif ooreenkom en die bedoeling van die Skrif reg weergee.

Calvyn sien verder dat die taak om die Woord van God reg te verkondig, nie net op die skouers van die predikant alleen rus nie. Die regte verkondiging is immers van lewensbelang vir die hele kerk, dit wil sê óók vir die lidmate. Dit is op hierdie punt dat Calvyn die beginsel invoer dat die prediking in die kerk gekontroleer, getoets sal word. Soos hy in sy 1 Korintiërs-kommentaar (14:29) stel, is dit nie die Woord van God wat aan die oordeel van mense onderwerp word nie, maar daar moet geoordeel word of die prediking inderdaad die Woord van God is wat aan die gemeente verkondig word en of dit slegs maar menslike denkbeelde is wat voorgedra word. Hierdie beoordeling is vanselfsprekend, want die predikant, hoewel organum van die Heilige Gees, bly altyd malus et peccator. Calvyn se standpunt in hierdie verband word goed weergegee wanneer hy in sy Handelinge-kommentaar (17:11) aanteken:

'Die Skrif is die ware toetssteen waarmee alle leerstellings getoets moet word. Indien enigiemand sou sê dat hierdie soort ondersoek problematies is, in dié sin dat die Skrif dikwels moeilik (verstaanbaar) is en op verskillende maniere uitgelê word, dan stel ek dat ons ook die oordeel van die Heilige Gees hier moet byvoeg. Want dit is nie sonder rede dat $\mathrm{Hy}$ die Gees van onderskeiding (discretionis) genoem word nie. Die gelowiges moet elke leerstelling nie ànders beoordeel as uit en volgens die Skrif nie met die Heilige Gees as hulle leier en gids.' 
Calvyn se siening is dus dat die gepredikte woord alleen die Woord van God kan wees vir sover dit met die Skriftuurlike Woord van God ooreenkom.

Calvyn se opvattings word in die kerklike orde opgeneem in Artikel 7 van die Geneefse Kerkorde van 1561 waar gestel word (Pont 1981: 23):

'Om elke gevaar te vermy dat die kandidaat (tot die dienswerk van die predikamp) een of ander dwaalleer aanhang, sal van hom 'n belofte geëis word dat hy hom aan die leer van die kerk, wat die kerk goedgekeur het, sal hou. Hier sal die inhoud van die Kategismus normatief wees.'

Terselfdertyd bepaal Artikel 20 (Pont 1981: 25) dat die diensdoende predikante weekliks bymekaar sal kom vir die bespreking van die Skrif 'met die doel om die suiwerheid van en die ooreenstemming met die leer te bewaar.'

Samevattend kan gestel word dat in die kerklike orde, soos Calvyn dit sien, die verkondiging van die Woord in die dienswerk van die predikant 'n gestalte kry alleen in die samehang van die sorgvuldige luister na die Heilige Skrif en die werking van die Heilige Gees (Milner 1970: 110).

Hierdie Calvinistiese beginsels het ook in die Nederlandse kerk gegeld hoewel daar ' $n$ bepaalde ontwikkeling was. Met die Convent van Wezel 1568 was dit nog voldoende dat die predikant mondeling belowe dat hy hom sou hou aan die leer van die kerk soos dit in die belydenis en die kategismus omskrywe word. Dit blyk egter om nie voldoende te wees nie en by Emden 1571 word van die predikant die formele ondertekening van die belydenis en die kategismus geëis. Die vraag wat dit presies beteken dat die predikant die formuliere van eenheid onderteken, word deur die daaropvolgende kerklike twiste oor die leer van die kerk al belangriker. Dit was die klassis Alkmaar wat in 1608 die eerste maal 'n ondertekeningsformule vir predikante opstel wat uit twee dele bestaan. Ten eerste is dit 'n verklaring van instemming met die Nederlandse Geloofsbelydenis en die Kategismus en ten tweede was dit ' $n$ belofte dat die ondertekenaar aan dié leer wil vashou en alle dwalings wat daarteen stry, openlik sal verwerp. Uit die beginpunt, onder die druk van die Arminiaanse twiste, ontwikkel die proponentsformule wat by die Sinode van Dordrecht 1619 vasgestel is (Pont 1981: 173-174). Dit is interessant dat die toetssteen van die prediking, deur die ondertekeningsformules, nou die belydenisskrif, as samevatting van die leer, geword het. Dié ontwikkeling was die direkte 
resultaat van die Arminiaanse twiste in die Nederlandse kerk èn die behoefte om 'n meer spesifiek-omlynde norm te hê. Dié posisie het die belydenisskrifte behou solank as wat die Calvinistiese presbiteriaalsinodale kerklike ordes in die Nederlandse kerke gegeld het. Met die invoering van die Algemeen Reglement in 1816 het dié situasie drasties verander. Nie alleen het hierdie nuwe kerkhke struktuur géén apparaat gehad om belydeniskwessies te hanteer nie, maar terselfdertyd is die toetsingsreg van die prediking daarmee oorboord gegooi. Verder is die beoordeling in hoever die belydenisskrifte, die norm vir die prediking, met die Woord van God ooreenkom, aan die persoonlike oordeel van die ampsdraer of lidmaat oorgelaat. Géén kerklike vergadering kon daaroor'n uitspraak maak nie (Rasker 1974: 42). Daarmee is 'n kerkverwoestende beginsel in die kerk ingedra, want daar kon toe geen oordeel meer gevel word oor die vraag wat regte prediking is nie. Geen wonder dat J I Doedes in 1854 geskryf het (aangehaal by Rasker 1974: 163):

'De Confusie komt in plaats van de Confessie. Niet de afwijking van de belijdenis der kerk, maar het ijveren voor de handhaving dier belijdenis wordt ketterij, en die het minst gunstig voor de leervrijheid en de met haar gepaarde ongebreidelde vrijzinnigheid gestemd zijn, moeten noodwendig voor de gevaarlijkste en meest zorgwekkende leden der gemeente gehouden worden.'

Hierdie 19de-eeuse ontwikkeling in Nederland en die verbrokkeling van die eenheid van die kerk in verskillende teologiese rigtings wat goed georganiseerd téénoor mekaar gestaan het, het 'n saad in die Nederlandse kerk gesaai waarvan die wrange vrugte tot vandag toe nog gepluk word. Geen kerk wat dit ernstig meen met sy roeping, opdrag en dienswerk kan straffeloos die beoordeling van die prediking, waardeur die kerk in stand gehou en gebou moet word, afskaf nie. Hoewel ons Kerk tot ongeveer die sestigerjare van hierdie eeu noue bande met dié Nederlandse kerk onderhou het, het ons Kerk hierdie Nederlandse voorbeeld nié nagevolg nie.

Voordat iets oor die historiese ontwikkeling in ons Kerk gesê word, is dit miskien tog belangrik om 'n paar opmerkings te maak oor enkele van die begrippe en verbande wat hier ter sake is. 


\section{ENKELE OPMERKINGS RONDOM DIE BEGRIP: DIE BELYDENIS}

Dit is seker nodig om oor die begrip die belydenis ' $n$ paar opmerkings te maak wat vir die doeleindes van hierdie uiteensetting nodig is. As gevra word na ' $n$ omskrywing dan kan gestel word dat ' $n$ belydenis nooit selfstandig ontstaan nie. Die belydenis is altyd antwoord, die antwoord van 'n mens, 'n kerk op die selfopenbaring van God in Jesus Christus. Dit wil sê: antwoord op die Woord van God. In dié sin kan gestel word dat die grondvorm van 'n belydenis is: Jesus Christus (is) die Here (Fil 2:11; 1 Kor 12:13). Verder is dit óók duidelik dat 'n belydenis méér is as 'n (gewone) verstandelike uitspraak, want dit is die uitspel van 'n eksistensiële lewenswaarheid, 'n waarheid wat geglo word.

Hierdie belydenis-as-'n-antwoord lei ook tot die ontstaan van die gemeente van gelowiges wat op grond van die selfopenbaring van God in Jesus Christus tot belydenis gekom het. Hierdie belydenis is antwoord, erkenning, aanvaarding in die geloof van Jesus Christus, wat $\mathrm{Hy}$ is en beteken. In dié sin het of besit die gemeente of die gemeenskap van die gelowiges nie 'n belydenis nie, maar die gemeente is in sy belydenis wat hy is. Daarom stel Artikel 27 NGB dat die kerk ' $n$ heilige vergadering van ware Christus-gelowiges is wat nie anders kan as om te bely dat Jesus Christus die Here is nie.

So gesien is ons Kerk ' $n$ belydende kerk wat die verpligting aanvaar om sy belydenis uit te spreek en wie se bestaan in die wêreld deur sy belydenis bepáál word (Kerkwet, Artikel l). So gesien is 'n belydenis nooit 'n objektiewe téénoor die belyer nie, maar altyd die eie antwoord. In 'n sekere sin is die uitdrukking die belydenis dus ' $n$ contradictio in terminis, want die belydenis is nié ' $n$ objektiewe gegewene nie. Hieruit kan gestel word dat die belydenisskrif nie dieselfde is as ' $n$ belydenis nie. Die belydenisskrif is slegs die skriftelike neerslag van 'n belydenis wat die eksistensiële geloof in Christus die Here uitdruk.

So gesien is dit ook duidelik waarom die belydenisskrif nié in die plek van die Heilige Skrif kan kom nie en altyd sekondêr ten opsigte van die Skrif is. Dit is, terloops, belangrik om daarop te wys dat die begrip sekondêr wat hier van die belydenisskrif gebruik word, tog 'n betreklike begrip is. Ons belydenisskrifte wil niks ánders sê as wat die Heilige Skrif self sê nie en as die Skrif, die skriftelik gefikseerde Woord van God, die regula fidei vir die gelowiges is dan is die belydenisskrif niks anders nie as die kort, in mens-woorde saamgevatte essensie van 
die regula fidei. Dit is wat elke predikant met sy handtekening by die proponentseksamen onderskrywe (Bepaling 73.2):

'... ek verklaar dat ek vas oortuig is en glo dat die leer wat in die formuliere van eenheid uitgedruk is, in volkome ooreenstemming met die Woord van God is."

Die enigste rede waarom die belydenisskrif as sekondêr aangedui kán word, is vanweẽ die feit dat die belydenisskrif, as mensewoord, tydelik en altyd hersienbaar is aan die hand van die Heilige Skrif. Ook vir die hersiening van die belydenisskrif het die kerk in sy orde 'n ordelike weg voorgeskryf sodat dit duidelik is dat dit nie net ' $n$ suiwer teoretiese saak is nie.

Histories gesproke kom ons belydenisskrifte (confessio) in die tyd van die Kerkhervorming na vore. Daarin word die hervormde verstaan van die sentrale boodskap van die Heilige Skrif weergegee en terselfdertyd is dit die samevatting van die aktuele belydenis van daardie hervormde kerke. As sodanig is die belydenisskrifte dus ook omskrywing van wie die hervormde gemeente is, soos duidelik blyk uit die manier waarop De Brès die NGB gebruik.

'n Ander interessante faset is dat die belydenisskrif ook as ' $n$ staatsregtelike dokument gebruik word. Met die Godsdiensvrede van Augsburg in 1555 waar die cuius regio eius religio-beginsel neergelê word, word die Confessio Augustana 'n dokument wat die godsdiens van ' $n$ land bepaal. Dit is dan dat die gedagte moontlik word dat ' $n$ kerk op ' $n$ belydenisskrif in plaas van op die Heilige Skrif self sal bestaan. Dan vervaag die gedagte ook dat 'n belydenisskrif ' $n$ belydenis bevat, dit wil sê ' $n$ antwoord op en 'n bevestiging van die geloof in Jesus Christus. Tog bly dit aan die ander kant waar dat die belydenisskrif strak en helder grense trek sodat die belydenisskrif sowel die omskrywing van die grense as die inhoud van die kerk uitspel. Dit is in hierdie verband duidelik en selfs vanselfsprekend dat die belydenisskrif ' $n$ sentrum en 'n periferie het, 'n sentrale moment waaromheen die res van die belydenisskrif gestruktureer is. Dit wil nie sê dat die periferiese niê van belang is nie, want byvoorbeeld in die gesprek met Rome is die aanduiding van die bron van die waarheid ' $n$ baie wesenlike saak terwyl dit, in ander gevalle, miskien van sekondêre betekenis sal wees. As dit so gestel word, word dit duidelik dat die opmerking dat die belydenisskrif ' $n$ sentrum en ' $n$ periferie het, nie beteken dat dele van die belydenisskrif nou maar verwaarloos of verwerp kan word nie, maar slegs dat die belydenisskrif se sentrum altyd ' $n$ belydenis is 
dat Jesus die Here is en dat daarvandaan die res van die inhoud van die belydenisskrif bepaal word. Steenkamp het hierdie saak uitvoerig beredeneer (Steenkamp 1982: 172-177) en dit is belangrik om te let op die feit dat Calvyn in hierdie verband praat van necessaria verae doctrinae capita. Ten oorvloede miskien kan hier verwys word na die opmerking van Nijenhuis (1959: 301):

'Voor Calvijn was het Woord Gods, het evangelium Christi, de pura et sana doctrina het wezenlijke kenmerk der kerk en het fundament van haar eenheid.'

Hieruit word duidelik wat die inhoud van die necessaria verae doctrinae capita is en dit is vanuit dié gesigshoek dat Calvyn, ondanks die gebreke wat hy daarin sien, die Confessio Augustana onderteken het (Schwarz 1962: 3, 885).

Interessant en rigtinggewend is in hierdie verband ons eie kerklike uitsprake oor hierdie saak. In die Kerkwet, Artikel XI.1 word gestel: '... bely die hele kerk ... sy geloof in die Drie-enige God' terwyl in XI.2 duidelik gesê word dat die belydenis vervat word in die belydenisskrifte. In die derde plek word in XI.3 gestel: 'Die Kerk bely ... telkens opnuut Christus as die Hoof van die Kerk en as Heer van die wêreld.'

Samevattend kan nou gestel word dat die belydenis in die kerk funksioneer as:

- aanduiding van die eenheid van die kerk,

- onderskeidingsteken van die ware geloof,

- verdediging of apologie, en

- middel om die ware geloof aan die nageslag oor te dra en in die wêreld te propageer.

Elkeen van dié fasette (Pont [1982]:7-8) hang saam met die belangrike slotafdeling van Artikel XI.4: 'Die Kerk weer uit sy midde alles wat die belydenis weerspreek.' Dié artikel verkry sy effektiwiteit vanweë die stellings in Artikel XX en die Bepalings wat daaruit voortvloei. Dit is op hierdie punt wat ons Kerk nog altyd ănders was as die Nederlandse Hervormde Kerk wat van die begin van die 19de eeu af in sy kerklike orde nié meer gesê het wăt dit beteken dat die kerk sy leer wil 'handhaaf' nie en ook nie 'n prosedure vir die handhawing van die leer neergelê het nie (Rasker 1974: 29). Dié 'vryheid', wat deur baie hoog geroem is, was in die grond van die saak 'n bandeloosheid wat die kerk gesekulariseer het en uitgelewer het aan die willekeur van mense. Dit 
is presies op hierdie punt waar elke keer in die lewe van die kerk besluit moet word of die gehoorsaamheid (geloof) aan God alléén belangriker is as die aansien by die mense. Dit is uit die geskiedenis van ons Kerk duidelik dat die bevoegde kerklike vergaderings nooit geskroom het om alles wat die belydenis van die kerk weerspreek, inderdaad uit sy midde te weer nie. Immers as dít nie gedoen word nie hou die kerk op daardie punt op om kerk te wees en word dit so iets soos 'n pure menslike vereniging.

As dit die tersaaklike is wat rondom die begrip belydenis gestel kan word, word dit ook nodig om iets te sê oor die begrip dogma in hierdie verband. Immers, as gestel word dat die belydenis in die belydenisskrif vervat word, dan word daarmee óók die samehang belydenis: dogma gestel want die belydenisskrif is dogma.

\section{RONDOM DIE BEGRIP DOGMA}

Die begrip dogma word in die Kerkwet nie as sodanig gebruik nie, maar dit word wel aangedui as die dogma omskryf word as die amptelike vasstelling van die leer van die kerk wat òf positief ' $n$ waarheid stel òf negatief ' $n$ onaanvaarbare opvatting afwys. Die oudste vorm van die dogma is die belydenis want die uitspraak dat Jesus die Here is, is ook 'n leerstellige of dogmatiese uitspraak. Dit dui verder daarop dat die dogma of die leer van die kerk in die lewe van die kerk nie 'n randverskynsel is wat die belangstelling van slegs enkeles verdien nie. As die dogma die verantwoorde uitdrukking van die inhoud van die Christelike geloof is, dan is dit duidelik dat dit langs die verkondiging in en van die kerk staan en direk daarby betrokke is. Dit kan gesê word dat dogma en prediking onlosmaaklik aan mekaar gekoppel is. Interessantheidshalwe kan daarop gewys word dat Basilius die Grote, 330-379, die éérste teoloog was wat 'n onderskeid gemaak het tussen die leer ( $t a$ dogmata) en die prediking (ta kerugmata). Daarby is dit opvallend dat Calvyn die begrippe woord, dogma, leer as wisselbegrippe vir verkondiging gebruik (Comm 1 Tim 5:17) en in sy uitleg van Efesiërs 2:20 sê hy: ' . . maar die kerk is op Christus gebou deur die verkondiging van die leer (= doctrina sacra).' So gesien, kan gesê word dat dit die funksie van die dogma is om wat in die kerk verkondig word, in die regte baan te hou sodat dit inderdaad regte verkondiging, in ooreenstemming met die Woord van God sal wees.

Miskien ten oorvloede kan daarop gewys word dat die dogma in die Kerk alléén tot stand kom deur 'n uitspraak of beslissing van die Algemene Kerkvergadering. Merkwaardig genoeg word dié bevoegdheid, 
wat altyd aan 'n sinodale vergadering toegekom het (Pont 1981: 236) in ons Kerkwet nié eksplisiet in Bepaling 11 genoem nie hoewel dit onder Bepaling 11.e tuisgebring kan word. Dit is verstaanbaar dat die formulering van die dogmata die taak van die Algemene Kerkvergadering is omdat dáármee gesê word wat die inhoud en omvang van die geloof, wàt die Kerk-as-'n-geheel in en deur die Bybel onder leiding van die Heilige Gees van God, van Jesus Christus en so meer verstáan het. Juis deur sy leeruitsprake streef die Kerk as geheel voortdurend daarna dat die verkondiging regte verkondiging sal wees want alleen deur die regte verkondiging word die Kerk opgebou èn voortgeplant. So is daar genoeg voorbeelde in die geskiedenis wat aandui dat as die kerk se sorg vir die regte verkondiging verslap of verdwyn, die kerk self agteruitgaan of selfs verdwyn, al gebeur dit ook nie dadelik nie.

Hieruit is dit duidelik dat die leer of dogma 'n mensewoord is. Dit is 'n poging om die inhoud van die Heilige Skrif teties-dogmaties uiteen te sit. Dit is in hierdie sin wat Martin Luther na die doctrina sacra verwys het as die heuning wat uit die blomme van die Heilige Skrif gehaal is. Dié doctrina sacra is 'n interpretasie, 'n benadering op menslike manier van die waarheid van God. Die leer of dogma of doctrina sacra is dus nié 'n openbaringswaarheid nie, maar 'n mensewoord en daarom voortdurend onderworpe aan die kritiese vraag of dit goeie of regte interpretasie van die Skrifwaarheid is. Tog is die doctrina sacra nie maar net ' $n$ mening nie, want vanweë die feit dat dit 'n verantwoorde uitspraak of beslissing van 'n bevoegde vergadering van die ampte is wat onder die leiding van die Heilige Gees besluit het (vgl Hand 15:28), het die doctrina sacra as kerklike beslissing 'n duidelike en omskrewe gesag. Hoewel dit 'n afgeleide gesag is, is dit tog méér gesaghebbend as die mening of opvatting van die enkeling. Omdat die dogma of doctrina sacra' $n$ mensewoord is, is dit hersienbaar. Hier moet egter gesê word dat 'n dogma alleen deur 'n Algemene Kerkvergadering verander kan word indien aangetoon word dat die Heilige Skrif self die Kerk as 't ware dwing om ánders te bely, sy geloofsinhoud anders te formuleer. Voorwaarde vir dié verandering is dus duidelike Bybelse getuienis.

Die kerklike ordening maak volledig voorsiening vir 'n moontlike hersiening van die dogma of die doctrina sacra of die belydenisskrifte van die kerk in Bepaling 75. Die opvallende van hierdie reëling is dat die predikant (of ook seker enige lidmaat) '... wat om skriftuurlike redes beswaard voel oor belydenisuitsprake (vgl Artikel XI) van kerklike vergaderings ...', dié beswaar skriftelik, met bewysstukke gestaaf, 
moet voorlê aan die Kommissie van die Algemene Kerkvergadering. Dié beswaar- of versoekskrif wat ' $n$ wysiging van die doctrina sacra beoog, die sg gravamen, moet vóórafgaan aan die openbare bekendmaking van sy besware. Dit word só gereël omdat die predikant steeds gebind bly deur sy handtekening onder die belofte wat hy afgelê het ná die proponentseksamen (Bepaling 73).

Dit wil dus sê dat die beswaarde in volledige lojaliteit aan en solidariteit mét die Kerk (= die volk van God, die liggaam van Christus) sy beswaar- of versoekskrif moet voorlê sodat die doctrina sacra, wat direk betrokke is by die regte verkondiging in en van die Kerk, wéér getoets kan word aan die regula fidei, dit is die Heilige Skrif sèlf.

Die argument dat die gravamen 'n inhoudlose gebaar is omdat die Algemene Kerkvergadering tog nie enige nuwe, ander insigte sal aanvaar nie, is 'n vals argument want die Kerk-as-geheel wéét dat ook die Kerk se dogmata niks méér is as 'n poging om die dogma te benader nie. Juis omdat die kerk in hierdie wêreld leef, kán geen kerklike uitspraak as finaal beskou word nie. Dit wil egter nie sê dat die doctrina sacra as 'n betreklike saak beskou moet word òf dat sonder meer aanvaar kan word dat die belydenisskrifte op ' $n$ verkrummelende fondament gebou is en dat daarom elkeen binne die Kerk maar kan maak, glo of bely soos hy self wil nie. Die doctrina sacra, die belydenisskrifte, die leer van die Kerk staan vas en is gesaghebbende kerklike beslissings wat nie sonder meer na menslike willekeur gewysig kan word nie. Tog bly dit hersienbare uitsprake en beslissings as die Heilige Skrif self ons dwing om ánders te glo en te bely.

Dit is, in die verbygaan, belangrik om daarop te let dat hoewel die dogma interpretasie, uitleg èn samevatting van die Bybelse getuienis is, daar nie ' $n$ bindende kerklike uitspraak oor die eksegese bestaan nie. Die eksegese as metode van uitleg is nié so belangrik nie, slegs die resultate is vir die verkondiging van belang.

Kortliks kan gestel word dat hoewel die Kerk nie oor die eksegetiese metode iets wil sé nie, dit vir die Kerk tog van belang is dat die eksegese regte uitleg van die Skrif sal wees. Die stelreël, wat uit Romeine 12:6 oorgeneem is, bepáál dat die eksegese net soos die verkondiging, die regula fidei as norm moet aanvaar. Dit was veral Augustinus wat dié opvatting baie sterk beklemtoon het (de doct chr III.2.2). Die uiterste konsekwensie van dié opvatting is deur die Roomse Kerk by Trente getrek waar, in afgrensing téén die Kerkhervorming, die sancta mater Ecclesia, die monopolie gegee word vir die uitleg van die Skrif.

Die Kerkhervorming het, ten opsigte van die uitleg van die Skrif, die 
stelreël neergelê dat die Skrif auf Christus hin, von Christus her (Weber 1955: I 358) verstaan moet word (Holl 1923: I 559). So het die reformatoriese stelreël scriptura sacra sui ipsius interpres ontstaan (Krusche W 1957: 188). Deur die vasstelling van hierdie reël, wat egter nie deel van die dogmata van die kerk is nie, word sowel die Roomse standpunt verwerp as dié van die sestiende-eeuse dwepers wat hulle so sterk beroep het op hulle 'besit' van die Heilige Gees en ook dié van die Humanisme wat deur middel van die 'verligte verstand' gedink het om die ideale sleutel vir die verstaan van die Heilige Skrif te besit.

Dit bly opvallend dat in die kerke van die hervorming die reformatoriese beginsel vir die eksegese nie altyd standgehou het nie en dat ook ànder hermeneutiese vertrekpunte gestel word. Tog bly die Kerk eis dat ongeag die eksegetiese metode, die resultate van die eksegese met die regula fidei gemeet moet en kan word. Dit, omdat die resultate van die eksegese die boustene vir die verkondiging is (wat op sy beurt één van die belydenismomente van die Kerk is, Artikel XI.3) en die verkondiging steeds onder die eis staan dat dit regte verkondiging, dit wil sê: in ooreenstemming met die Woord van God, moet wees.

\section{ENKELE OPMERKINGS OOR BEPALING 73}

As nou verder gevra word na implikasies wat die funksie van die belydenis en dogma in die kerklike struktuur vir die predikant het, dan kan dit in die eerste plek verklaar word deur te let op die ondertekeningsformule. Dit val, wat ons Kerk betref, histories gesproke in drie periodes.

Die eerste periode is dié van 1652-1804 wanneer die gemeentes in die Kaapkolonie organies en organisatories deel is van die Nederlandse Kerk. Vanweë die patronaatskap van die VOIC oor dié gemeentes, is dit miskien nié so opvallend nie. Dwarsdeur die historiese termyn van die VOIC, behalwe vir die kort termyn van die eerste Britse besetting van die Kaap wanneer die band enigsins dun geskaaf is, val die Kaapse gemeentes onder die sorg van die klassis Amsterdam. Dit is dié klassis wat die predikante, wat in die VOIC se struktuur diens gedoen het, toegelaat en bevestig het (Spoelstra 1906: I LV). Dié predikante was almal verplig om die NGB en die Heidelbergse Kategismus te onderteken '... tot meerder verseeckeringe van de enicheyt der lere...' (Reitsma en Van Veen 1892: I 427) en nà 1619 het hulle ook die Dordtse formule (Pont 1981: 174-175) onderskryf. 
Die nuwe bedeling wat deur Kommissaris-Generaal De Mist se Kerken-orde van 1804 ingelui is en in 1824 lei tot die invoering van 'n eie Kerkwet het nie veel hieraan verander nie. Dit het meegebring dat vanaf 1837 'n eie ondertekeningsformule vir aankomende predikante opgestel is waarin onder andere gestel is (Engelbrecht 1953: 213).

'...verklaren opregt en in goeden gemoede voor den Heer, met deze onze naamtekening, dat wij van harte gelooven, dat al de Artikelen en Stukken der leer, in de Belijdenis en Catechismus ... begrepen, met Gods Woord overeenkomen...'

Die Sinode van 1837 het nog verder vasgestel (Handelingen 1837, 1858: 141):

'De Synode verklaart, dat de ondertekenaar van de Acte bij legitimatie door zijne onderteekening verklaart en te kennen geeft, dat hij de leer, die in de Formulieren van Eenigheid vervat is, gelooft overeenkomstig Gods heilig Woord te sijn.'

Dié Kaapse formulier is deur die predikante Van der Hoff, Begemann en Smits onderteken. Nadat die Kaapse Kerk die legitimasie van hierdie predikante in 1863 ingetrek het, was ons Kerk verplig om self sy predikante tot die evangeliebediening toe te laat. In 1866 is die proponentsondertekeningsformule, soos ons dit vandag nog het, opgestel en deur die Algemene Kerkvergadering aanvaar (Engelbrecht 1953: 214).

As gelet word op Bepaling 73 dan is ten eerste belangrik dat die ondertekenaar verklaar:

'Ek ... verklaar hiermee dat ek die leer wat uitgedruk is in die formuliere van eenheid, naamlik die NGB, die HK en die DL, en wat in ooreenstemming is met die Woord van God, van harte onderskryf èn getrou sal verkondig.'

Hoewel die Kommissie van die Algemene Kerkvergadering nog nie ' $n$ verklaring van die begrip leer in Bepaling 73 gegee het nie, is dit tog duidelik dat die leer waarna verwys word die doctrina sacra is in dié sin waarin Calvyn dié begrip hanteer het. Dit gaan dus nié om ' $n$ abstrakte leer of dogma as sodanig nie, maar om die necessaria verae doctrinae capita wat ooreenstem met die regula fidei, dit is die Woord van God. Dié saak word juis deur Artikel XI só vasgelê en in dié sin is Artikel XI, wat vanaf 1951 in ons Kerkwet staan, 'n belangrike nadere omskrywing 
van die begrippe wat hier gebruik word. Terselfdertyd word hier beklemtoon dat die dogma en die verkondiging onlosmaaklik aan mekaar gekoppel is, vandaar dat die heelhartige aanvaarding van die doctrina sacra uitmond in die getroue verkondiging daarvan omdat die doctrina sacra die tetiese samevatting is van die inhoud van die Woord van God.

Daarnà stel die kandidaat:

'Deur hierdie formule te onderteken, verklaar ek dat ék vas oortuig is en (dat ek) glo dat die leer wat in die formuliere van eenheid uitgedruk is, in volkome ooreenstemming met die Woord van God is.'

Hiermee verklaar die kandidaat dat die kerklike belydenis, soos vervat in die belydenisskrifte, vir hom nie 'n objektiewe belydenis is nie, maar dat hy soos die Kerk en saam met die Kerk glo en dat die kerklike formulering van die belydenis óók uitdrukking van sy geloof is. Daarom is die kerklike belydenis nié ' $n$ historiese stuk uit die gryse verlede nie, want deur sy ondertekening maak die kandidaat self dit 'n eie en eietydse belydenis. In dié lig gesien, kan die belydenis of die doctrina sacra nooit 'n dwang of 'n keurslyf wees nie, want dit is, kragtens sy handtekening, vir elke predikant óók die uitdrukking van sy eié belydenis, sy eie antwoord op die Woord van God.

Die derde saak wat die kandidaat beloof of verklaar, word so geformuleer:

'Ek beloof verder om my stiptelik te hou aan die orde wat neergelê is in die Wet en Bepalings van die Kerk en by oortreding daarvan my te onderwerp aan die oordeel van die bevoegde kerklike vergaderings.'

Daarmee word belowe dat die predikant hom óók stiptelik sal hou by die orde-reëlings in verband met besware oor die belydenis. Dit wil, volgens Bepaling 75, sê dat 'n dienaar van die Woord enige beswaar oor die belydenis éérs 'skriftelik en met bewysstukke gestaaf' voor die Kommissie van die Algemene Kerkvergadering sal lê. Hier sê die dienaar van die Woord sy onvoorwaardelike lojaliteit en solidariteit aan die Kerk toe, want die dienaar is volkome bewus daarvan dat die Kerk as geheel dit nooit kan gedoog dat'n situasie ontstaan waar die belydenis van die Kerk as ' $n$ voorwaardelike belydenis of 'n belydenis wat op losse skroewe staan of wat sommerso bevraagteken kan word, beskou word nie. Die dienaar van die Woord aanvaar dus hier die verantwoor- 
delikheid om homself te dissiplineer, ter wille van sy medegelowiges, om op 'n ordelike weg sy besware, wat die resultaat van sy eie sorgvuldige studie is, aan die bevoegde kerklike vergadering voor te lê.

Die gedagte wat soms gehoor word, dat die weg van die beswaarversoekskrif 'n onmoontlike weg is omdat 'n Algemene Kerkvergadering tog nooit sy belydenisskrifte sal hersien nie, is die argument van die ongeloof. Immers ' $n$ meerdere vergadering in die Kerk neem juis in so ' $n$ saak sy besluite op grond van die Skrif en onder leiding van die Heilige Gees. Daarom kan niemand ooit by voorbaat sê dat 'n Algemene Kerkvergadering nie ' $n$ beswaar- of versoekskrif noulettend en sorgvuldig sal ondersoek nie.

Die hersiening van die belydenis het, in 'n sekere sin, met die verloop van die tyd 'n vergete punt op die agenda van ons sinodale vergaderings geword omdat daar alleen by wyse van hoë uitsondering 'n sodanige versoek- of beswaarskrif voorgelê is. As daar teruggegaan word in die geskiedenis is dit nogal opvallend dat in die beginjare van die Nederlandse Kerk, die hersiening van die belydenis 'n vaste agendapunt vir die sinodale vergadering was. Die ontstaan van die Arminiaanse twiste en die opkoms van die gereformeerde skolastiek met sy spitsvondigheid en vitterigheid, het die provinsiale Sinode van NoordHolland 1607 laat besluit om die nasionale sinode te versoek (Reitsma en Van Veen 1892: I 413):

‘... dat in de vytschryvinge des nationalen synodi de clausule van revisie der Confessie ende des Catechismi (daerin haer de kercken doorgaens seer beswaren, dewyl sy deselve voor schriftmatich houden) tot gemeene ruste ende vrede van de kercken ende om andere gewichtige redenen uyt te laten off dat in de plaetse van deselve min quetselycke woorden te stellen, niettemin verstaende dat in den synodo nationali de Confessie der Nederlantscher kercken niet moet, maer sal mogen overlesen worden, indien de synodus om voorvallende oorsaecken sulcx noodich vint, ende dat het dengenen, die yet daertegen hebben, vry staan tselve debite in te brengen om by den synodo na Gods woord te laten overwegen, oordeelen ende afhandelen.'

Dié versoek toon duidelik dat die nasionale sinodes, met die vaste punt op die agenda, vanselfsprekend en normaalweg na die belydenisskrifte gekyk het. Dit was ook die vaste taak van die nasionale sinode (Pont 1981: 236). 
'n Nuwe situasie ontstaan in dié sin dat vanaf 1619 tot 1816 daar nooit weer in Nederland ' $n$ nasionale sinode gehou is wat oor die leer, die belydenisskrifte en hulle inhoud kon handel nie. Met die nuwe struktuur wat die Nederlandse Kerk in 1816 ontvang het, word volgens die verenigingsreg waarop die kerk nou gebou is, géén bevoegdheid aan die sinode verleen om ò die belydenisskrifte te hersien òf oor die leer te handel nie. Die gevolg is dat dié saak van die sinodale agenda verdwyn het en so word deur die verloop van die tyd die indruk geskep dat die belydenisskrifte onaantasbaar is, terwyl dit nié die geval is nie.

In ons Kerk waar die taak van die nasionale sinode ten opsigte van die belydenisskrifte en die leer ook nie eksplisiet omskrywe is nie, mede as gevolg van die historiese gang van sake, en waar wysigings in die belydenisskrifte deur Artikel XIII.4 nog verder ingewikkeld gemaak word, kan die foutiewe opvatting bestaan dat die belydenisskrifte omtrent nie wysigbaar is nie. Dit is egter, in die lig van ons calvinistiese erfenis, nié 'n houdbare opvatting nie, al sou Artikel XIII.4 daardie indruk wil skep.

Vir Artikel XIII.4 self bestaan daar deugdelike gronde om dit te behou, veral in die lig van Artikel I waar ons die Kerk op 'n beskeie, nie-gearriveerde manier, omskrywe. Dié saak kan egter nie hier nou verder gevoer word nie. Ten slotte kan net samevattend wéér gestel word (Pont 1981: 243) dat in die lig van Bepaling 73 die dienaar van die Woord sèlf aanvaar dat solank hy die belydenisskrifte (= die bondige, kerklike samevatting van die regula fidei) nie deur 'n versoek- of beswaarskrif bevraagteken het nie, dit die norm èn reël vir sy prediking en sy hantering van die doctrina sacra is en bly. In hierdie verband is die belydenisskrifte die gesaghebbende aanduiding van die inhoudelike grense van die Kerk. Indien oor daardie grens gegaan word, word die eenheid van die geloof en die eensgesindheid, wat vir die Kerk onontbeerlik is, versteur. In Bepaling 73 verbind die dienaar van die Woord hom onherroeplik om daardie eenheid van die geloof en die eensgesindheid in die Kerk te help bewaar, onder andere deur homself te dissiplineer ook op hierdie vlak.

\section{DRIE BELANGRIKE LEERTUG-GEVALLE IN ONS KERK}

In ons Kerk het daar drie belangrike leertug-gevalle voorgekom. ' $n$ Kort bespreking daarvan kan miskien verdere duidelikheid bring oor hoe die belydenis en dogma ten opsigte van die predikant in ons Kerk 
funksioneer. In aldrie hierdie gevalle blyk dit dat daar in die Kerk nie so iets soos 'n 'kerklike polisiemag' of so iets soos 'n Roomse Inkwisisie bestaan wat noulettend en speurend elke dienaar van die Woord voortdurend kontroleer om vas te stel of hy nie dalk op een of ander punt die gesaghebbende norm en reël oortree nie. Ook word die belydenisskrifte nié gebruik as 'n soort 'finale antwoord' in die teologiese debat waarmee die teenstander tot gedweë swye gebring moet of kan word nie. Die belydenisskrifte funksioneer as norm en reël, as gesaghebbende samevatting van die regula fidei, maar tog behou die Skrif en sy uitsprake die primaat in die prediking en in die teologiese debat as die vraag na die regte verkondiging en die regte leer gevra word. Dit blyk ook uit die gevalle van leertug wat in ons Kerk voorgekom het.

\subsection{Die geval van ds A J Begemann}

Ds A J Begemann, wat deur sy optrede en uitsprake meerdere male onrus en beroering in sy gemeente Pretoria veroorsaak het, moes hom op 11 Maart 1872 voor die Kommissie van die Algemene Kerkvergadering verantwoord oor ' $n$ klag wat teen hom gelê is.

Ds Begemann het eers in ' $n$ private gesprek en daarna in ' $n$ kerkraadsvergadering verklaar dat I Johannes 5:7'n latere toevoeging tot dié brief sou gewees het en dat dieselfde geld van die eerste verse van Johannes 8 . Verder sou hy óók gesê het: '... dat men grooten oogen zoude opzetten, indien alles bekend werd wat hij wist.' Interessantheidshalwe kan net vermeld word dat die Nuwe Afrikaanse Vertaling in ' $n$ voetnoot vermeld: Volgens die gebruikte grondteks is Johannes 7:53-8:11 eers later ingevoeg. By I Johannes 5:7 is daar géén aantekening nie.

Die saak wat ds Begemann aangeroer het en waaroor hy aangekla is, was in die grond van die saak of die Skrif'n gesaghebbende mededeling van die Godsopenbaring was of nie. Dié uitsprake, waarskynlik gekoppel aan die feit dat hy al vantevore beroeringe in sy gemeente veroorsaak het, het tot die klag aanleiding gegee.

Die Kommissie het in 'n sorgvuldige uitspraak, onder andere die volgende gestel (Engelbrecht 1953: 261):

'Het vraagstuk, waarover gehandeld is, is niet eene questie van leer, maar van wetenschap... .

Maar juist omdat het eene zaak van wetenschap is, en door verschil van gevoelen als twijfelachtig moet worden aangemerkt, wenscht de heele Commissie van hare zijde het duidelijk te doen 
uitkomen, dat zij elke daad, die strekken kan om het gezag van den Bijbel bij de gemeente te verminderen, afkeurt, als zijnde gevaarlijk, ontijdig en onnodig. Gevaarlijk, omdat daardoor de deur wordt opengezet voor minachting van den Bijbel.

Ontijdig. De uitkomsten van de onderzoeking der Godgeleerden zijn zoo twijfelachtig, en er bestaat zooveel verschil van gevoelen dienaangaande, dat het geheel ontijdig kan geacht worden, de gemeente bekend te maken met de wetenschappelijke vraagstukken, die zij toch niet kan beoordeelen. Onnodig, omdat de Bijbel, zooals die thans voor ons ligt, en als zoodanig in de Nederduitsch Hervormde gemeente gebruikt wordt, voldoet aan de behoeften, om de weg der zaligheid te doen kennen, die voor de gemeente van het hoogste en enigste belang is om te weten. De Commissie wil de gebezigde woorden van den Predikant A J Begemann als zoodanig beschouwen, daar zij berekend zijn om kwaad en geen goed te doen, terwijl een dienaar van het Evangelie zich beijveren moet om te vergaderen en niet om te verstrooijen, en de les van voorzichtigheid in acht te nemen, die ook in den Bijbel wordt aanbevolen.'

Op grond van hierdie bevinding, is ds Begemann vir drie maande geskors met verlies van traktement. Volgens die Kerkwet 1869 het die Kommissie nie die bevoegdheid gehad om ds Begemann af te sit nie, want dit was die prerogatief van die Algemene Kerkvergadering self. In sy bevinding het die Kommissie aangedui wat die norm van beoordeling was wat aangelê is. Dit was Artikel I van die Wet waar gestel word:

'... de Nederduitsch-hervormde kerk in de ZAR grondt zich op de leer van de bybel, als Gods heilig woord; den Heidelbergschen Catechismus; de 37 artikelen der Nederlandsche geloofsbelydenis en de 5 Dordtsche leer-regels, zoo-als die zyn vastgesteld in 1618 en 1619 te Dordrecht.'

Daarby ook Artikel 41 wat die proponentsondertekeningsformule bevat. Dit is dus duidelik dat die belydenisskrifte, as die gesaghebbende, saamgevatte regula fidei, hier as norm hanteer is. Op grond daarvan dat ds Begemann dié norm oortree het, is hy skuldig bevind. Verder kan oor hierdie saak nog gestel word dat die Kommissie hier die goeie reg van teoloë om met wetenskaplike ondersoek en studie van die Skrif besig te wees, volkome billik. Wat die Kommissie hier veroordeel, is die manier waarop dié (voorlopige) resultate te berde 
gebring is, '... daar zij berekend zijn om kwaad en geen goed te doen ....'Die kwaad wat gestig is, is dat ds Begemann se opmerkings die gesag van die Bybel, die Woord van God, in gedrang gebring het by die lidmate wat dit nie in perspektief kan beoordeel nie. Juis deur dit te doen, het ds Begemann eerder verstrooi as om te vergader, en dít druis wéér in teen die Heilige Skrif as regula fidei.

Ten slotte kan in hierdie verband opgemerk word dat hierdie probleem ná die geval Begemann nog nie wéér in die Kerk voorgekom het nie. Miskien sou mens kon herhaal wat Johannes Calvyn as die belangrikste kenmerk van die Kerk gestel het, naamlik dat die regte verkondiging die regte hoor en gehoorsaamheid moet volg (Institusie IV.1.9). As die regte hoor ontbreek, dan kan die afleiding gemaak word dat daar géén regte verkondiging was nie.

\subsection{Die geval van ds C J L Ruysch van Dugteren}

Aangesien hierdie saak uitvoerig deur Botha (Botha 1981: $200 \mathrm{vlg}$ en Botha [1983]: $38 \mathrm{vlg}$ ) behandel is, kan hier net op die belangrikste momente gelet word. Ds C J L Ruysch van Dugteren is op 8 April 1909 as predikant van Pretoria bevestig. In 'n skrywe van 7 Julie 1911 aan die Kommissie van die Algemene Kerkvergadering het hy navraag gedoen oor die strekking en betekenis van sy ondertekening van die proponentsformule en onder andere gestel:

'Zou het $\mathrm{u}$ meening mocht zijn, dat $\mathrm{ik}$ mij als predikant te houden hebt aan de belofte bij in dienst treden afgelegd, - dan voel ik mij gedrongen hier openlijk te verklaren, dat ik de leer in de drie formulieren van eenigheid vervat, niet volkomen kan gelooven overeenkomstig Gods Woord te zijn.'

Sy primêre beswaar was veral gerig téén die Dordste Leerreëls en bepaalde frases daarin. Terwyl die Kommissie van die Algemene Kerkvergadering besig was om dié saak te ondersoek, het ds Van Dugteren op 28 Julie 'n ope brief aan die Kerkraad van Pretoria gerig en dit ook in die gemeente versprei. Daarin het hy verklaar dat hy sy ondertekening van die proponentsformule as ' $n$ formaliteit beskou het en dat hy nie die belydenis van die Kerk hartlik kan omhels en getrou kan leer nie, aangesien hy die leer van die uitverkiesing nie kan aanvaar nie (Botha 1981: 217). Hierna het ds Ruysch van Dugteren 'n Open brief gepubliseer wat aan al die lede van die Kerk gerig was. Hier het hy wéer verklaar dat hy vry wil wees van alle bande wat sy gewete bind, dus 
óók van die ondertekening van die belydenisskrifte (Engelbrecht 1953: 371). Hiermee het hy, in feite, sy ondertekening van die proponentsformule teruggetrek en gestel dat sy belofte dáár nie meer staan nie.

Op 7 September 1911 het die Kommissie van die Algemene Kerkvergadering byeengekom om ds Ruysch van Dugteren te antwoord op sy skrywe van 7 Julie aan die Kommissie en sy daaropvolgende skrywes. Nadat die Kommissie ds Van Dugteren self óók aangehoor het, het die Kommissie verklaar (Botha 1981: 202):

'Dat de Commissie zelf staande onder de wet, op de vraag van ds C J L Ruysch van Dugteren, of een predikant der NHK van SA zich letterlyk moet houden aan de formule van art 116 der wet (die proponentsformule), geen ander antwoord kan geven, dan dat zy geroepen om de wet te handhaven, geene afwyking van de leer mag toelaten, en dat zy afwykingen van de leer der drie formulieren van Eenigheid moet beschouwen als strydig met de belofte by de indiensttreding van een leeraar afgelegd;

Dat de Hervormde Kerk in Zuid Afrika geene leervryheid kan toestaan en ook nooit toegestaan heeft, wat tot ontbinding der kerk zou kunnen leiden;

Dat van de predikanten verwacht wordt, dat zy zich aan hunne onderteekening zullen houden, en wanneer zy daartegen bezwaar mochten hebben zy dié dan brengen ten bevoegder plaatse en niet van den kansel voor de gemeente.

Dat de Commissie meent dat ds C J L Ruysch van Dugteren door zyne verklaring dat hy zich zeer bezwaard gevoelde over zyne onderteekening van art 116, en hy zich niet langer daaraan kan houden, zich zelve aan het predik ambt in de NHK in ZA heeft onttrokken.'

Die Kommissie het dus bevind dat ds Van Dugteren met die terugtrekking van sy onderskrywing van die proponentsformule en dus sy aanvaarding van die belydenis van die Kerk, opgehou het om predikant van die Kerk te wees. In 'n antwoord op ds Van Dugteren se Open Brief het die Kommissie onder andere die volgende gestel (De Hervormer, 15 Sept 1911: 3):

'U gelooft niet, volgens uw eigen vrijwillige verklaring, dat de leer in de formulieren van enigheid volkomen overeenkomstig Gods Woord is. De verklaring dat sy overeenkomstig Gods Woord zijn, is door $\mathrm{u}$ onderteekend en aangesien dit een vrywillige verklaring 
was, waardoor alleen $u$ de toegang tot de kerk werd verleend, laat het geen de minste twyfel over dat $u$ niet meer thuis behoort in de kerk van het ogenblik dat u zulk een nieuwe verklaring gemaakt heeft.'

Dit alles het die Kommissie in 'n skrywe aan die Kerkraad van Pretoria nog 'n keer toegespits met die stelling:

'... dat ds Ruysch van Dugteren door het terugnemen van zijne handteekening zich buiten de kerk heeft gesloten, en daardoor heeft opgehouden diensdoend predikant der NHK te zijn;...'

Ds Van Dugteren was nie met die uitspraak van die Kommissie tevrede nie en het hom op 'n Algemene Kerkvergadering beroep. Op 30 April 1912 het die Algemene Kerkvergadering saamgekom om dié beroep aan te hoor. Van Dugteren het egter nooit opgedaag nie waarna die Algemene Kerkvergadering, nadat hy volledig oor die gang van sake ingelig is, die optrede en handelinge van sy Kommissie goedgekeur het (Botha 1981: 203).

Dié saak het nog 'n nadraai gehad in dié sin dat dr HDJ Bodenstein, 'n vriend van Van Dugteren, in 1911 'n brosjure gepubliseer het: Schorsing van ds Ruysch van Dugteren: Wordt de Hervormde Kerk Roomsch? Daarop het ds M J Goddefroy in 1912 geantwoord met 'n brosjure: Neen! Niet Roomsch. Omdat hierdie materiaal uitvoerig deur Botha behandel is, word daar nie verder op ingegaan nie behalwe om daarop te wys dat Goddefroy se behandeling van die vraag na die strekking van die proponentsformule van besondere waarde is.

In die geval van Van Dugteren het ons, soos in die bogaande vermeld is, te make met 'n nogal unieke geval. Deurdat Van Dugteren sy ondertekening van die proponentsformule teruggetrek het, het hy nie alleen kontrakbreuk gepleeg nie (Pont 1962: 70), maar óók te kenne gegee dat hy nie meer soos die Kerk en saam met die Kerk glo nie. Vir Van Dugteren het die belydenisskrifte, waarin die belydenis van die Kerk verwoord is, nie meer gegeld as die gesaghebbende samevatting van die regula fidei, die Heilige Skrif nie. Sonder om die oop pad van die versoekskrif in verband met die belydenis te gaan, het hy die belydenisskrifte tot argaïese, nie meer toepaslike uitdrukkings van die geloof van die Kerk verklaar en hom, teenoor die belydenisskrif op die Skrif alléén, vir sy standpunt beroep. Tereg het die Kommissie verklaar dat Van Dugteren se optrede nie aanvaar kan word nie, want dít sou 
neerkom op die aanvaarding van volledige leervryheid 'wat tot ontbinding der kerk zou leiden'. Juis deur so die belydenis van die Kerk uit die pad te wil stoot, het Van Dugteren hom buite die amp èn die kring van die gelowiges geplaas.

\subsection{Die geval van prof A S Geyser}

Die geval van prof A S Geyser herinner in 'n sekere mate aan die geval van ds A J Begemann omdat dit hier ook gegaan het om die beoefening van die eksegese èn die resultate daarvan. Ook hier het die vraag na die binding van die belydenisskrifte na vore gekom.

Die ondersoek na die klag wat deur drie senior teologiese studerte $\mathrm{H}$ $G$ van der Westhuizen, E Engelbrecht en W C M de Beer in September 1961 by die Kommissie van die Algemene Kerkvergadering ingedien is, was ' $n$ omvattende saak. Die ondersoek wat in Oktober 1961 begin het, het voortgeduur tot die einde van November en is voortgesit op 30 Januarie 1962 en afgesluit op 4 April 1962. Die getikte weergawe van die ondersoek en wat daar gesê is, beslaan 2672 bladsye.

In sy Bevinding en Uitspraak het die Kommissie die saak waaroor dit gegaan het, as volg saamgevat:

'Die klag hou in dat die aangeklaagde, hoofsaaklik in sy eksegese van Filippense 2:6-11 maar ook in sy uitleg van ander Skriftuurplekke sowel as deur middel van uitlatings tydens die onderrig van ander vakke, sy studente onderrig het op 'n wyse wat eksklusief ruimte laat vir die opvatting dat:

(a) Christus in status voor sy menswording sowel as daarna, ondergeskik was aan God.

(b) die post-eksistente Christus 'n hoër status beklee as die preeksistente Christus.

Die klaers voer aan dat die aangeklaagde sodoende

(a) afgedoen het aan die waaragtige, ewige Godheid van Christus en sodoende

(b) die belydenis van die Kerk in die Athanasianum in art 6 sowel as in art 24 bestry het.'

Hoewel daar nog verdere klagtes was, was dit die kern waarom dit gegaan het. Die klag het versoek dat die Kommissie die uitsprake van prof A S Geyser sou meet aan die norm van die belydenisskrif. 
Geyser het in sy verweer baie klem gelê op die vryheid van die eksegeet in die beoefening van sy wetenskaplike studie en onderrig. Hy het gestel dat hy, terwyl hy met Skrifondersoek besig was, nie gedwaal het nie, want dit is die tradisionele standpunt van ons Kerk dat die Skrif vry is van enige vorm van belydenisdwang. Hieruit volg dan die vryheid van die eksegeet ook tot beoefening van die eksegetiese eksperiment, sonder inagneming van die belydenisskrifte. Geyser het dié vryheid eers as absoluut gekwalifiseer en later gekwalifiseer as onderworpe aan sy gebondenheid aan wat daar in die teks staan èn sy gebondenheid aan die God waarin hy glo.

In sy Bevinding het die Kommissie nogal uitvoerig op dié saak ingegaan. Dit is terloops belangrik om daarop te let dat die Kommissie nie net vasgestel het wát Geyser gesê het en dit toe aan die uitspraak van die belydenisskrifte gemeet het nie. ' $n$ Besondere opdrag is aan die Vergadering van Professore gegee om 'n pre-advies op te stel in terme van Artikel 23 en Artikel 28 van die Kerkwet. In die pre-advies moes, onder andere, 'n uiteensetting gegee word oor: Wat is dwaalleer? wat is die reg en vryheid van die eksegeet; wat leer die belydenisskrifte oor: die aard en natuur van die Heilige Drie-eenheid, die status van die preen post-eksistente Christus, die Heilige Gees, die wese en karakter van die algemene, Christelike kerk? Wat beteken die begrippe morphe, ousia, phusis in die verband van die Heilige Skrif en die belydenisskrifte en in die ontwikkeling van die dogma van die kerk.

Hierdie pre-advies van die Vergadering van Professore, hoofsaaklik opgestel deur prof B J Engelbrecht, is van besondere waarde omdat dit nié alleen die uitsprake van die belydenisskrifte beredeneer nie, maar voortdurend die Skriftuurlike basis èn agtergrond van die uitsprake na vore bring. Die pre-advies wat bedoel was om die beoordelingsnorm aan die Kommissie te verhelder, is juis daarin belangrik dat hier geïmpliseer word dat in 'n leertugsaak nie nét na die belydenisskrifte geluister kan word nie, maar óók na die Heilige Skrif as die regula fidei.

In sy Bevinding het die Kommissie dan nie nèt op die uitsprake van die belydenisskrifte gelet nie, maar die hele aangeleentheid beredeneer. Oor die vryheid van die eksegeet, het die Kommissie gestel:

'Die Kommissie kan geen uitspraak gee oor die vraag of 'n eksegese reg of verkeerd is nie, want dan sou die Kommissie 'n standaard eksegese van ' $n$ bepaalde Skrifgedeelte of gedeeltes moet gee, wat dan vervolgens bindende gesag vir die kerk sou moet wees. Die Kommissie kan alleen oordeel oor die vraag of 'n eksegeet in die Bybel of in 'n Skrifgedeelte ' $n$ boodskap verneem het 
wat verenigbaar is met die boodskap wat die Kerk in die Bybel verneem het of nie. Hoe die Kerk die boodskap van die Bybel verneem het, het die Kerk neergelê in sy belydenisskrifte en om die waarheidsgehalte hiervan te beoordeel lê buite die bevoegdheid van die Kommissie. Dit is die taak van die Algemene Kerkvergadering en daarmee hang 'n duidelike voorgeskrewe prosedure saam.'

Daarna het die Kommissie oor die vryheid van die eksegeet gehandel. Dit was één van die sake waaroor daar lank gepraat is. Miskien is dit tog belangrik om enigsins uitvoerig die bevinding van die Kommissie hier aan te haal.

'Die Kommissie handhaaf die beproefde standpunt van die Nederduitsch Hervormde Kerk, naamlik dat die Skrif vry is van enige vorm van belydenisdwang. Dit het egter ... nie beteken dat die NHK leervryheid beoefen nie. Die vryheid van die Skrif beteken nie dat die Skrifondersoeker vry is van enige vorm van belydenisgebondenheid nie. Die Skrif spreek soewerein sonder inagneming van die uitsprake van die Belydenis.... Die aanvaarding van die vryheid van die Skrif noodsaak die Kerk tot die bereidheid om anders te bely wanneer die Woord van God in die Skrif deur die Kerk ànders verneem word.

Verneem die Skrifondersoeker die Woord van God anders (as in die belydenisskrif) is die Kerk bereid om na hierdie Skrifondersoeker te luister op 'n wyse waarvoor die Kerk duidelik riglyne neergelê het. Intussen is sodanige Skrifondersoeker nie belet om die Woord van God so te verneem soos hy dit verneem het nie; alleen is hy nie toegelaat om sý individuele verneem van die Woord van God te stel bókant of selfs teenóór die verneem van daardie selfde Woord deur die Kerk nie.'

Teen hierdie agtergrond het die Kommissie duidelik gestel dat daar vryheid vir die eksegese bestaan, maar wys dan daarop dat die vryheid van die eksegese nie sonder meer uitloop in die vryheid van die individuele eksegeet nie, want dan lewer die kerk homself uit aan die gevaar van subjektiwistiese eksegese.

Dan beredeneer die Kommissie die argument dat die eksegeet nie alleen in die Kerk is nie en dat die Skrifmatigheid van die leer van die Kerk nié deur die individuele eksegeet gewaarborg word nie, maar deur die geheel van die gelowiges wat elkeen die Bybel in die hand het. 
Immers, stel die Kommissie dat hoewel die bydrae van vakeksegete van groot belang is vir die regte verstaan van die Skrif, gee dit aan hulle nie ' $n$ absolute vryheid nie, want die regte verstaan van die Skrif is die resultaat van die testimonium Spiritus Sancti onder die geheel van die gelowiges. Die eksegeet het nie die reg om die erkenning van die resultate van sy studie vooruit te loop nie, maar hy moet wag op die erkenning wat deur die testimonium Spiritus Sancti onder die gelowiges bewerkstellig word. Dan stel die Kommissie:

'Maar voorbarige uitsprake uit eie insig moet hy ook nie maak nie sonder om oorwoë uitsprake van bevoegde kerklike outoriteite, in ooreenstemming met die voorskrif van die Kerk, in dié verband af te wag nie. En as hy self oorwoë uitsprake maak, wat hom nie verbied is nie, moet hy in elk geval dit nie doen sonder die gepaste erkenning van die mindere gewig van eie resultate vergeleke met die oorwoë uitsprake van bevoegde kerklike outoriteite in die verlede nie.'

In hierdie verband het die Kommissie Geyser toegegee dat die eksegeet vry is in die beoefening van sy wetenskaplike arbeid behoudens sy gebondenheid aan wat daar staan in die Skrifgedeelte waarmee hy besig is en aan die God in wie hy glo. Die Kommissie stel in hierdie verband:

'Die Kommissie stel egter as voorbehoud by sy gebondenheid aan die God in wie hy glo, dat die God in wie Hy glo, dié God sal wees in wie die Kerk glo, en geen ander god nie. Sonder hierdie gebondenheid sou sy die (eksegeet) vryheid inderdaad bandeloosheid wees. Die Kerk glo in die God van die Bybel. En die Kerk ken die God van die Bybel só soos hy Hom bely in sy belydenisskrifte.

Hierdie kennis is nooit finaal of volmaak nie want die God wat Hom in die Bybel openbaar, is ewig en die belydenisskrifte van die Kerk is die resultaat van die begrip van mense wat verganklik is; ... hierdie kennis behoef dringend en voortdurend volgehoue aanvulling en korreksie uit die konfrontering met die lewende spreke van die ewige God self deur sy Gees en in sy Woord. Om die Kerk te dien in hierdie volgehoue aanvulling en korreksie van die Belydenis van die Kerk op grond van die konfrontering met die Woord van God in sy geheel deur die Kerk, is die gekwalifiseerde reg en vryheid van die eksegeet. Om eiehandig aan te vul of te korrigeer, is misbruik van sy vryheid.' 
Dan wys die Kommissie daarop dat die situasie in die lesinglokaal, wat aanleiding tot die klag gegee het, van so ' $n$ aard was dat dit duidelik is dat die grense wat hier getrek is, oorskry is.

Daarna het die Kommissie breed ingegaan op Filippense 2:6-11, die pre-advies van die Vergadering van Professore in aanmerking geneem, onder andere die vraag gestel èn beantwoord of die gegewens in die teks 'die aangeklaagde genoop het om eksklusief só te eksegetiseer soos hy gedoen het', en ook nog op ànder fasette gelet, en toe gestel:

'Die Kommissie bevind dat die resultaat van die eksegese van die aangeklaagde nie verenigbaar is met die Belydenis van die Kerk oor die onderlinge verhouding van die drie Persone in die heilige Drievuldigheid van God, soos vervat in die Athanasianum art 6 en artikel 24, en soos uitvoeriger beredeneer in die betrokke gedeelte van die advies van die Professorevergadering nie.'

Dit word hiér duidelik dat die Kommissie die belydenisskrifte as norm hanteer, maar dat dié norm vóóraf aan die Skrif self, as regula fidei getoets is.

In sy uitspraak, wat op die bevinding gevolg het, het die Kommissie by die oorweging of daar versagtende of verswarende oorwegings is wat in berekening gebring moet word, ook daarop gewys dat die manier waarop Geyser opgetree het die aanleiding tot die klag was en met inagneming van dié verswarende omstandighede, is Geyser uit sy amp as predikant van die NHK afgesit.

Dit was nie die einde van die saak nie, aangesien Geyser hom toe op die Hooggeregshof beroep het. Dié gebeure is egter vir die doeleindes van hierdie bespreking nie ter sake nie.

Dit het in hierdie saak wéér duidelik geword dat leervryheid nié in ons Kerk aanvaar en toegelaat word nie so lank as wat Bepaling 73, die proponentsformule, so bly staan nie. Daardie belofte, wat elke dienaar van die Woord vrywillig aflè, is 'n kontraktuele verbintenis wat aangegaan word waar die dienaar van die Woord vir homself ' $n$ bepaalde gedragslyn aanvaar vir sy dienswerk. Daar aanvaar hy óók dat die belydenisskrifte van die Kerk as die saamgevatte regula fidei sal geld wanneer hy 'n klag oor sy leer moet beantwoord.

\section{SLOTOPMERKINGS}

Uit die voorgaande opmerkings is dit duidelik dat die funksie van die belydenis en die dogma in óns Kerk vir'n groot deel bepaal word deur 
ons opvatting van die kerk. Dié omskrywing word nie alléén deur die Kerkwet (Artikel I-III) en in die belydenisskrifte gegee nie, maar óók deur die opvatting dat ons 'n volkskerk is of wil wees (Botha 1973). Dit beteken dat ons nie so iets soos 'n kerkverband is of besit nie en dat die belydenis dus ook nie funksioneer as die akkoord van die kerklike gemeenskap of die basis van die kerkverband nie. Vandaar dat in ons Kerkwet die belydenis én die belydenisskrifte eers in Artikel XI na vore kom waar die geloofsinhoud van die kerk in verband met die verkondiging van die kerk (Artikel XII) omskryf word. Belangrik vir die selfomskrywing van ons Kerk is ook Artikel XIII.4 waaruit blyk dat, in ons opvatting, die grense van die kerk wyer lê as die grense van ons Kerk, soos Artikel I dit ook reeds impliseer. Vir òns Kerk is dit nie alleen belangrik dat ons almal in die Kerk reg sal glo nie (vgl Artikel 7 NGB), maar ook dat die Kerk die evangelie suiwer preek (Artikel 29 NGB). Dit is rondom dié begrip suiwer preek dat die belydenisskrifte as saamgevatte norm en reël na vore kom op grond van Bepaling 73. Te alle tye egter handhaaf die Kerk die primaat van '... die Woord van God wat deur die werking van die Heilige Gees bron en enigste inhoud van die prediking en reël van die geloof is,' (Artikel XI.1). Hier is nié 'n gaping tussen die Woord van God en die belydenisskrifte nie en die Kerk laat ook nie toe dát daar 'n gaping sal ontstaan nie, vandaar die voorgeskrewe ordelike weg indien 'n gelowige meen om so 'n gaping te konstateer. Dit is hier opvallend hoe die Kommissie van die Algemene Kerkvergadering in die verskillende leertuggevalle en ook by ander geleenthede met nadruk verklaar het dat ons Kerk géén leervryheid toelaat nie. Daarin verskil ons radikaal van die Nederlandse Hervormde Kerk met wie ons 'n band en goeie betrekkings sou wil behou (Artikel XXIII). Die gevalle van leertug wat in ons Kerk voorgekom het en wat in die gevalle van Ruysch van Dugteren en Geyser opspraak in die openbaar veroorsaak het, het ontstaan omdat die uitsprake én optrede van die aangeklaagdes in die kring van die gelowiges beroering en on rus veroorsaak het. In aldrie die gevalle het die Kommissie van die Algemene Kerkvergadering sorgvuldig na die klaers èn die aangeklaagdes geluister en elke keer die norm van die belydenisskrif aangelê om die gewraakte stellings te toets nadat dié norm aan die Skrif sèlf gemeet is. Sodoende is daar steeds gewaak dat die grense van die Kerk, soos omskryf deur die belydenisskrifte, duidelik gebly het. 


\section{Literatuurverwysings}

BOTHA, SJ 1973. Die volkskerk. Pretoria: HAUM.

BOTHA, SJ 1981. Ds Marié Joseph Goddefroy 1848-1920. Sy lewe en betekenis. Pretoria: HAUM

BOTHA, SJ [1982]. Die belydenis in kerkregtelike verband. HTS 38/2 \& 3, 30-44.

ENGELBRECHT, SP 1953. Geskiedenis van die Nederduitsch Hervormde Kerk van Afrika. Pretoria: HAUM.

KRUSCHE, W 1957. Das wirken des Heiligen Geistes nach Calvin. Göttingen: Vandenhoeck \& Ruprecht.

MILNER, BC 1970. Calvin's doctrine of the church. Leiden: Brill.

NIJENHUIS, W 1959. Calvinus Oecumenicus. Den Haag: Nijhoff.

PONT, AD [1961]. Die Kerkwet en die amp van dienaar van die Woord. HTS 17, 66-82.

PONT, AD 1981. Die historiese agtergronde van ons kerklike reg. Pretoria: HAUM.

PONT, AD [1982]. Die belydenis in historiese verband. HTS 38/2 \& 3, 1-29.

REITSMA, J \& Van Veen, SD. Acta der provinciale en particuliere synoden. Deel I: NoordHolland. Groningen: JB Wolters.

RASKER, AJ 1974. De Nederlandsche Hervormde Kerk vanaf 1795. Kampen: Kok.

SCHWARZ, R 1962. Johannes Calvins Lebenswerk in seinen Briefen, BD III. Moers: Neukirchener Verlag.

STEENKAMP, JJ 1982. Unitas notae ecclesiae, in Die Kerk in die wêreld: 'n Bundel opstelle aangebied aan prof dr AD Pont by sy 25-jarige ampsjubileum, 171-182. Pretoria: HAUM.

SPOELSTRA, C 1906. Bouwstoffen voor de geschiedenis der Nederduitsch-Gereformeerde Kerken in Zuid-Afrika. Deel I. Kaapstad: HAUM.

WET EN BEPALINGS VAN DIE NEDERDUITSCH HERVORMDE KERK VAN AFRIKA 1983. Pretoria: NHW-Pers.

WEBER, O 1955. Grundlagen der Dogmatik. Erster Band. Moers: Neukirchener Verlag. 